\title{
Eupatilin-7-O-2,6-Dirhamnosylgalactoside From The Leaves Of Boerhaavia Diffusa Linn.
}

\author{
Navabha Joshi ${ }^{1}$, D.L. Verma ${ }^{2}$ \\ ${ }^{1,2}$ (Department of Chemistry, S. S. J. campus, Kumaon University, Almora-263601, Uttrakhand, India)
}

\begin{abstract}
Boerhaavia diffusa (Nyctaginaceae), commonly known as Punarnava, has been used to cure various ailments since vedic, unani and ayurvedic periods. Keeping in view the medicinal importance of the punarnava extracts among various ethnic groups of the Himalayas, the reducing potential of aqueous methanolic extract derived from the aerial parts of the plant was evaluated. The n-butanol soluble fraction from water-ethanolic extract, which was found to be a potent anti-oxidative and highly enriched with quercetin glycosides, was fractionated on whatmann N3 PC using BAW (butanol-acetic acid-water in the ratio 4:1:5, v/v, upper layer) as a developing solvent. Antioxidant activity- guided fractionation of chromatographically isolated flavonol positive fraction led to the isolation and characterization of Eupatilin-7-O- $\alpha$-rhamnosyl $(1 \rightarrow 2) \alpha-$ rhamnosyl $(1 \rightarrow 6)-\beta$-D-galactopyranoside a non-catechol group flavone and two flavonol glycosides viz. Quercetin-3,7-di-O-glucoside and Quercetin-3-O- $\alpha$-L-rhamnosyl $(1 \rightarrow 6)-\beta$-galactopyranoside from active catechol-group flavonoid fractions. The antioxidant activity of the isolates were determined against DPPH free radicals and their structures were elucidated by chromatographic, spectral $\left({ }^{1} \mathrm{H} N M R,{ }^{13} \mathrm{C} N M R, L C-M S\right)$ and hydrolytic methods (acid, $\mathrm{H}_{2} \mathrm{O}_{2}$ and enzymatic).
\end{abstract}

Keywords - Boerhaavia diffusa linn., eupatilin, antioxidant activity, flavonol glycoside, flavones

\section{Introduction}

Boerhaavia diffusa (Nyctaginaceae), is a flowering plant distributed in tropical, subtropical and temperate regions of the world at an elevation of $700 \mathrm{ft}$ to $7000 \mathrm{ft}$. It is a profusely branched, perennial, creeping and pubescent, ascending herb with a height of about $70 \mathrm{~cm}$. The leaves of the plant are simple, thick, fleshy, short petiole, ovate-oblong and up to $5.5 \times 3.3 \mathrm{~cm}^{2}$ in area. Its flowers are minute, yellow and white colored present four to ten together forming axillary and terminal panicles. Flowering in the plant is observed in the months of October and November. Punarnava is distributed over the hot Himalayan valley from $500 \mathrm{ft}$ to 6000 $\mathrm{ft}$. Forty species of Boerhaavia have been reported, six of which viz., B.diffusa, B.chinensis, B.erecta, B.repens, B.rependa, and B.rubicunda are found in India (Chopra, 1969; CSIR, 1988) ${ }^{[1]}$. Only one species,i.e., Punarnava (Boerhaavia diffusa) is reported from Indian Himalayan region (Gaur, $1999^{[2]}$; Pangtey, $2005^{[3]}$ ). Boerhaavia diffusa is a traditional medicinal plant of Kumaon Himalayan region. In Ayurvedic, Siddha, Unani and Homeopathic systems of medicine, the plant has been used to treat nephritic syndrome (Singh and Udupa, $1972)^{[4]}$, asthama, jaundice, drosical swelling, worm infections, liver troubles, heart troubles, urinary tract infections, cough, cold and inflammation (Lad, $1999^{[5]}$; Guhabakshi et al., $1999^{[6]}$ ). In Kumaon hills Boerhaavia diffusa leaves have also been used as a vegetable for better health (Pangtey,2005). The extracts derived from different parts of the plant exhibit a wide range of biological activities, viz. anti-inflammatory (Bhalla et al., 1971 ${ }^{[7]}$ ); hypoglycemic (Chude et al., 2001) ${ }^{[8]}$; antifibrinolytic (Jain and Khanna,1989) ${ }^{[9]}$; anticonvulsant (Adesina, 1979) ${ }^{[10]}$; anti-nematodal (Vijaylakshmi et al., 1979) ${ }^{[11]}$; anti-urethritis (Nadkarni, $1976)^{[12]}$; anti-bacterial (Olukoya et al., 1993) ${ }^{[13]}$; anti-hepatotoxic (Misra, $1980^{[14]}$; Chandan et al., $1991^{[15]}$ ); antiviral (Awasthi and Menzel, 1986) ${ }^{[16]}$; and antioxidant (Pari and Satheesh, 2004) ${ }^{[17]}$. The present investigation reveals the isolation and identification of flavonol-glycosides from antioxidant activity- guided fractionation of ethyl acetate (EtOAc) and n-butanol (n-BuOH) soluble fractions of aqueous methanolic extract of Boerhaavia diffusa.

\section{Materials And Methods}

1. Plant material: The aerial parts of Boerhaavia diffusa were collected from Kathgodam, a part of terai bhabar and foothill forming region of Kumaon. The flower bearing twig of the plant was authenticated by Prof. P.C. Pandey, Department of Botany, Kumaun University, S.S.J. campus, Almora-263601, Uttarakhand, and deposited in the same department with herb specimen No. FL-P-003.

2. Extraction and isolation of flavonoid positive fractions: Three $\mathrm{kg}$ dried and powdered aerial parts of Boerhaavia diffusa were extracted sequentially with $80 \%$ methanol $(\mathrm{MeOH})$ and $50 \%$ aqueous $\mathrm{MeOH}$ by cold percolation method for six days. The two extracts were filtered and combined. The combined extract was concentrated in vacuo until only $\mathrm{H}_{2} \mathrm{O}$ layer (approx. $60 \mathrm{ml}$ ) remained. It was partitioned with $50 \%$ 
Eupatilin-7-O-2,6-dirhamnosylgalactoside from the leaves of Boerhaavia diffusa linn.

dichloromethane $\left(\mathrm{CH}_{2} \mathrm{Cl}_{2}\right)$. The $\mathrm{CH}_{2} \mathrm{Cl}_{2}$ soluble fraction was separated and the remaining $\mathrm{H}_{2} \mathrm{O}$ layer was further partitioned with diethyl ether, ethyl acetate and n-butanol successively. Each partition was examined for antioxidant activity against DPPH (free radical) by the standard thin layer autobiography $\left(\mathrm{SiO}_{2}\right)$ method (Cuendet et al., 1997) ${ }^{[18]}$. Diethyl ether, EtOAc and n-BuOH soluble fractions produced three, four and three positive spots, respectively against DPPH reagent.

The diethyl ether soluble antioxidative fraction produced three spots on TLC and was evaluated for total flavonoid positive compound by 2 DPC using BAW (4:1:5, upper layer) and 30\% HOAc as a developing solvent. 2 DPC examination revealed the presence of five fluorescent spots under UV $(360 \mathrm{~nm})$ light, three of which were identified as flavonoids on the basis of color reactions with NA (Naturstoff reagent-A), ammoniacal silver nitrate, $\mathrm{ZrOCl}_{2}$ and $\mathrm{FeCl}_{3}-\mathrm{K}_{4} \mathrm{Fe}(\mathrm{CN})_{6}$ reagents. Among three flavonoid positive compounds, only one was identified to catechol-grouping flavonoid (Mabry and Markham, 1975) ${ }^{[19]}$. The three flavonoid positive constituents were isolated by RPPC using 30\% acetic acid (HOAc) as a developing solvent. Each component was finally purified by sephadex LH-20 CC using 50\% aqueous methanol as an eluent. The three components from diethyl ether fractions were referred to as $\mathrm{A}, \mathrm{B}$ and $\mathrm{C}$ in order of their decreasing mobilities on PC with $30 \%$ HOAc as a developing solvent.

The $\mathrm{n}-\mathrm{BuOH}$ soluble anti-oxidative fraction was adsorbed on cellulose $\mathrm{CC}$ and eluted initially with $\mathrm{H}_{2} \mathrm{O}$ and then with 20\%HOAc, 30\% HOAc, 40\% HOAc and 50\% HOAc successively. On eluting CC with $30 \%$ HOAc, two dark purple fluorescent bands were observed and each was eluted and collected separately by monitoring under UV light. The eluates derived from faster and slower moving band were referred to as Frac.I and Frac. II respectively and the former was found to have more antioxidant potential amongst the two. RPPC of Frac. I using BAW (4:1:5, v/v, upper layer) as a developing solvent afforded two broad dark purple fluorescent bands which were eluted and collected separately in order of their decreasing mobilities and named as Frac. I(a) and Frac. I(b) respectively. Frac. I(a), negative to catechol grouping flavonoid and less anti-oxidative compared to Frac. I(b), was chromatographed on sephadex LH-20 CC using 40\% aqueous methanol as an eluent. A broad dark purple fluorescent band was observed on CC. It was eluted and referred to as compound D. Frac.I(b), positive to catechol-grouping flavonoids and highly anti-oxidative was adsorbed on sephadex LH-20 CC and eluted successively with $\mathrm{H}_{2} \mathrm{O}, 10 \% \mathrm{MeOH}, 20 \% \mathrm{MeOH}, 30 \% \mathrm{HOAc}, 40 \% \mathrm{HOAc}$ and $60 \% \mathrm{HOAc}$. A total of 50 fractions, $100 \mathrm{ml}$ each, were collected. Each fraction was examined on cellulose(Merck) TLC using $15 \%$ HOAc as developing solvent and catechol grouping flavonoids were characterized by spraying with ammonical $\mathrm{AgNO}_{3}$ and NA(reagents). Chromatographically similar catechol grouping flavonoids bearing fractions were combined. Two major fractions derived from fractions $30-40(50 \% \mathrm{MeOH})$ and fractions $42-49(60 \% \mathrm{MeOH})$ afforded two compounds, (E) and (F) respectively.

\section{Results And Discussion}

The Compounds B and C were identified as Kaempferol and Quercetin respectively on the basis of comparison with their respective standards by PC. . The spectral data of the two compounds were also found in agreement with the literature values of Kaempferol and Quercetin .(Agrawal, $1989^{[20]}$; Markham and Geiger,1994) ${ }^{[21]}$.

The compound A appeared as dull yellow fluorescent streak on PC under UV light both in the absence and presence of $\mathrm{NH}_{3}$ vapors indicating a flavone with free hydroxyl group at 5-position (Mabry et-al, 1970) ${ }^{[22]}$. EIMS of the compound A exhibited a molecular ion peak at $\mathrm{m} / \mathrm{z} 334(\mathrm{M})^{+}$and other prominent ion peaks at $\mathrm{m} / \mathrm{z}$ $343,329,301,167,165,139$ and $111 .{ }^{1} \mathrm{H}$ NMR (in DMSO-d $\mathrm{d}_{6}, 400 \mathrm{MHz}$ ) showed signals at $\delta 6.411(1 \mathrm{H}, \mathrm{s}$ ), $\delta 6.399(1 \mathrm{H}, \mathrm{s}), \delta 3.743(3 \mathrm{H}, \mathrm{s}), \delta 7.493(1 \mathrm{H}, \mathrm{dd}, \mathrm{J}=1.733, \mathrm{~J}=0.587), \delta 3.765(3 \mathrm{H}, \mathrm{s}), \delta 6.940(1 \mathrm{H}, \mathrm{dd}, \mathrm{J}=8.425$, $\mathrm{J}=0.587), \delta 7.738(1 \mathrm{H}, \mathrm{dd}, \mathrm{J}=8.425, \mathrm{~J}=1.733), \delta 3.950(3 \mathrm{H}, \mathrm{s})$. Thus compound A has been deduced to be 2- $(3,4-$ dimethoxyphenyl)-5,7- dihydroxy-6-methoxychromen-4-one or Eupatilin. Further the $\mathrm{CH}$ - unsubstituted and $\mathrm{OCH}_{3}$ group substituted positions in aromatic systems were confirmed by HECTOR $\left({ }^{13} \mathrm{C}\right.$ NMR).

Two flavonol glycosides, $\mathrm{E}$ and $\mathrm{F}$ were isolated from most prominent antioxidant active catechol-group flavonoid positive fractions. The compound (E) appeared as dark purple fluorescent band on PC under UV light and gave positive colour reactions with $\mathrm{Mg}+\mathrm{HCl}$ and $\alpha$-naphthol. Complete acid hydrolysis of $\mathrm{E}$ with $2 \mathrm{~N} \mathrm{HCl}$ afforded Quercetin (CoPC) and Glucose (CoPC). $\mathrm{H}_{2} \mathrm{O}_{2}$ oxidation of E gave Quercetin-7-O- $\beta$-Dglucopyranoside (CoPC) and glucose (CoPC). LC-MS (ESI-) of E gave a molecular ion peak at $\mathrm{m} / \mathrm{z} 625[\mathrm{M}-\mathrm{H}]^{-}$ and other prominent ion peaks at m/z $463(\mathrm{~m} / \mathrm{z} 625$ - glucose) and m/z $301(\mathrm{~m} / \mathrm{z} 463$ - glucose), indicating the release of two glucose moieties from quercetin. ${ }^{1} \mathrm{HNMR}$ showed five aromatic signals for quercetin and two anomeric proton signals at $\delta 5.56(1 \mathrm{H}, \mathrm{d}, \mathrm{J}=7.5 \mathrm{~Hz})$ and $\delta 5.26(1 \mathrm{H}, \mathrm{d}, \mathrm{J}=7.30 \mathrm{~Hz})$ which have been attributed to two primary glucose moieties attached respectively to C-3 and C-7 positions of Quercetin. Thus compound (E) has been identified as Quercetin-3-O- $\beta$-D-glucopyranoside- 7-O- $\beta$-D-glucopyranoside. The compound (F) has been identified as Quercetin- 3-O- $\alpha$-L-rhamnopyranosyl $(1 \rightarrow 6)$ - $\beta$-D-galactopyranoside. Its chromatographic behavior, hydrolytic products (acid, enzyme, $\mathrm{H}_{2} \mathrm{O}_{2}$ ) and spectral data (UV, ${ }^{1} \mathrm{HNMR},{ }^{13} \mathrm{C}$ NMR and MS) were found similar to those already reported in the literature to Quercetin- 3-O- $\alpha$-L-rhamnopyranosyl $(1 \rightarrow 6)$ - $\beta$-Dgalactopyranoside. 
Eupatilin-7-O-2,6-dirhamnosylgalactoside from the leaves of Boerhaavia diffusa linn.

Compound (D) appeared as dark purple fluorescent band on PC under UV light which turned yellowgreen with $\mathrm{NH}_{3}$, indicating the presence of 5-hydroxyl group in the flavone (Mabry et-al, 1970; Markham, $1982)^{[23]}$. The methanolic solution of $\mathrm{D}$ gave positive colour reactions with $\mathrm{Mg}+\mathrm{HCl}$ and $\alpha$-naphthol, indicating a flavonoid glycosidic compound. Complete acid hydrolysis of D with 2- $\mathrm{NHCl}$ afforded eupatilin(CoPC), galactose (CoPC) and Rhamnose (CoPC). LC-FABMS (-) of D exhibited a molecular ion at m/z 797 [M-H] $]^{-}$and two prominent peaks at m/z 651 (m/z 797-rhamnose) and m/z 343 \{m/z 797-(galactose + rhamnose) \} supporting the ionization of two molecules of rhamnose and one molecule of glucose from eupatilin. Enzymatic hydrolysis of $\mathrm{D}$ with $\alpha$-rhamnosidase afforded a flavone glycoside, represented as $\mathrm{D}(\mathrm{a})$. The compound $\mathrm{D}(\mathrm{a})$ appeared as dark purple fluorescent spot on PC under UV light which turned yellow- green with $\mathrm{NH}_{3}$, indicating a flavone with free hydroxyl groups at 5- position.( Mabry et-al, 1970). Complete acid hydrolysis of D(a) with 2N HCl gave an aglycone, eupatilin (CoPC) and a sugar, galactose( CoPC). LC-MS (negative mode) of D(a) gave a molecular ion peak at m/z 505 and other prominent ion peaks at m/z $343(\mathrm{~m} / \mathrm{z} 505$ - galactose) indicating the release of galactose from the eupatilin galactoside. The compound $\mathrm{D}(\mathrm{a})$ was identified as eupatilin-7-O- $\beta$-Dgalactopyranoside on the basis of its ${ }^{1} \mathrm{HNMR}$ and ${ }^{13} \mathrm{C}$ NMR (aglycone). The rhamnose sugar was identified from the mixture obtained by the complete acid hydrolysis of the compound (D). Thus it has been established that both the rhamnose moieties substitute the hydroxyl groups of primary sugar, galactose.

${ }^{1} \mathrm{HNMR}\left(\mathrm{DMSO}-\mathrm{d}_{6}, 400 \mathrm{MHz}\right)$ of D exhibited two doublets at $\delta 1.274(3 \mathrm{H}, \mathrm{d}, \mathrm{J}=6.900)$ and $\delta 1.279(3 \mathrm{H}$, $\mathrm{d}, \mathrm{J}=6.900$ ) for the two methoxy substituents at $\mathrm{C}-3$ and C-4 in the B-ring of the flavone and a singlet at 83.950 for a methoxy group at C-6 of the A-ring. Three anomeric proton signals at $\delta 5.299(1 \mathrm{H}, \mathrm{d}, \mathrm{J}=10.260), \delta 4.509$ $(1 \mathrm{H}, \mathrm{d}, \mathrm{J}=2.920)$ and $\delta 4.430(1 \mathrm{H}, \mathrm{d}, \mathrm{J}=2.920)$ were attributed to galactose ( $\beta$-configuration), rhamnose $(\alpha-$ configuration) and rhamnose ( $\alpha$-configuration), respectively. The terminal sugars, rhamnose moieties are attached to C-2" and C-6" of galactose (primary sugar) as evident from the ${ }^{1} \mathrm{H}$ NMR data. Thus the compound D has been identified as Eupatilin 7-O- $\alpha$-L-rhamnopyranosyl $(1 \rightarrow 2) \alpha$-L-rhamnopyranosyl $(1 \rightarrow 6)$ - $\beta$-Dgalactopyranoside.

IV. Figures And Tables

${ }^{13}$ C NMR (DMSO-d 6 ) data of Eupatilin (aglycone).(Table 1).

\begin{tabular}{|l|c|c|c|}
\hline Shift & attribution & Shift & attribution \\
\hline 163.4 & C-2 & 122.9 & C-1' \\
103.3 & C-3 & 109.3 & C-2' \\
182.2 & C-4 & 149.0 & C-3' \\
131.3 & C-6 & 152.0 & C-4' \\
157.3 & C-7 & 111.6 & C-5, \\
94.4 & C-8 & 120.0 & C-6' \\
104.1 & C-10 & $60,55.8,55.7$ & CCH $_{3}$ 's \\
\hline
\end{tabular}

${ }^{1} \mathrm{H}$ NMR (DMSO-d 6 , $\left.400 \mathrm{MHz}\right) \square$ ppm ofD(a).

$\delta 3.950(3 \mathrm{H}, \mathrm{s}), \delta 3.764(3 \mathrm{H}, \mathrm{s}), \quad \delta 3.742(3 \mathrm{H}, \mathrm{s}), \delta 7.284(1 \mathrm{H}, \mathrm{dd}, \mathrm{J}=8.395, \mathrm{~J}=1.654), \delta 6.984(1 \mathrm{H}, \mathrm{dd}, \mathrm{J}=8.395$, $\mathrm{J}=0.919), \delta 7.501(1 \mathrm{H}, \mathrm{dd}, \mathrm{J}=1.654, \mathrm{~J}=0.919), \delta 6.419(1 \mathrm{H}, \mathrm{s}), \delta 6.751(1 \mathrm{H}, \mathrm{s}), \delta 3.997(2 \mathrm{H}, \mathrm{d}, \mathrm{J}=5.119), \delta 3.440$ $(1 \mathrm{H}, \mathrm{td}, \mathrm{J}=5.119, \mathrm{~J}=2.680), \delta 3.443(1 \mathrm{H}, \mathrm{dd}, \mathrm{J}=3.470, \mathrm{~J}=2.680), \delta 3.624(1 \mathrm{H}, \mathrm{dd}, \mathrm{J}=10.170, \mathrm{~J}=3.470), \quad \delta 3.256$ $(1 \mathrm{H}, \mathrm{dd}, \mathrm{J}=10.260, \mathrm{~J}=10.170), \delta 5.153(1 \mathrm{H}, \mathrm{d}, \mathrm{J}=10.260)$

${ }^{1} \mathrm{H}$ NMR (DMSO-d 6 , $\left.400 \mathrm{MHz}\right) \delta$ ppm of D.

$\delta 3.950(3 \mathrm{H}, \mathrm{s}), \delta 3.765(3 \mathrm{H}, \mathrm{s}), \delta 3.741(3 \mathrm{H}, \mathrm{s}), \delta 1.274(3 \mathrm{H}, \mathrm{d}, \mathrm{J}=6.900), \delta 1.279(3 \mathrm{H}, \mathrm{d}, \mathrm{J}=6.900), \delta 7.658(1 \mathrm{H}, \mathrm{dd}$, $\mathrm{J}=8.525, \mathrm{~J}=1.567), \delta 7.177(1 \mathrm{H}, \mathrm{dd}, \mathrm{J}=8.525, \mathrm{~J}=5.424), \delta 7.559(1 \mathrm{H}, \mathrm{dd}, \mathrm{J}=5.424, \mathrm{~J}=1.567), \delta 6.421(1 \mathrm{H}, \mathrm{s}), \delta$ $6.755(1 \mathrm{H}), \delta 4.128(2 \mathrm{H}, \mathrm{d}, \mathrm{J}=4.559), \delta 4.187(1 \mathrm{H}, \mathrm{dq}, \mathrm{J}=10.260, \mathrm{~J}=6.900), \delta 4.129(1 \mathrm{H}, \mathrm{dq}, \mathrm{J}=10.260, \mathrm{~J}=6.900)$, $\delta 3.562(1 \mathrm{H}, \mathrm{td}, \mathrm{J}=4.559, \mathrm{~J}=2.680), \delta 3.372(1 \mathrm{H}, \mathrm{dd}, \mathrm{J}=10.260, \mathrm{~J}=10.170), \delta 3.360(1 \mathrm{H}, \mathrm{dd}, \mathrm{J}=10.260, \mathrm{~J}=10.170)$, $\delta 3.848(1 \mathrm{H}, \mathrm{dd}, \mathrm{J}=3.470, \mathrm{~J}=2.680), \delta 3.904(1 \mathrm{H}, \mathrm{dd}, \mathrm{J}=10.170, \mathrm{~J}=3.450), \delta 3.778(1 \mathrm{H}, \mathrm{dd}, \mathrm{J}=10.170, \mathrm{~J}=3.450), \delta$ $3.512(1 \mathrm{H}, \mathrm{dd}, \mathrm{J}=3.450, \mathrm{~J}=2.920), \delta 3.328(1 \mathrm{H}, \mathrm{dd}, \mathrm{J}=3.450, \mathrm{~J}=2.920), \delta 3.750(1 \mathrm{H}, \mathrm{dd}, \mathrm{J}=10.170, \mathrm{~J}=3.470), \delta$ $4.430(1 \mathrm{H}, \mathrm{d}, \mathrm{J}=2.920), \delta 4.509(1 \mathrm{H}, \mathrm{d}, \mathrm{J}=2.920), \delta 5.229(1 \mathrm{H}, \mathrm{d}, \mathrm{J}=10.260), \delta 3.560(1 \mathrm{H}, \mathrm{dd}, \mathrm{J}=10.260$, $\mathrm{J}=10.170$ )<smiles>COc1ccc(-c2cc(=O)c3c(O)c(OC)c(O)cc3o2)cc1OC</smiles><smiles>O=c1c(O)c(-c2ccc(O)cc2)oc2cc(O)cc(O)c12</smiles> 
<smiles>O=c1c(O)c(-c2ccc(O)c(O)c2)oc2cc(O)cc(O)c12</smiles>

C<smiles>COc1ccc(-c2cc(=O)c3c(O)c(OC)c(O[C@@H]4O[C@@H](CO[C@H]5O[C@@H](C)[C@@H](O)[C@H](O)[C@H]5O)[C@@H](O)[C@H](O)[C@H]4O)cc3oc2=O)cc1OC</smiles>

D

$\mathbf{D}(\mathbf{a})$<smiles>COc1ccc(-c2cc(=O)c3c(O)c(OC)c(O[C@@H]4O[C@H](CO)[C@@H](O)[C@H](O)[C@H]4O)cc3o2)cc1OC</smiles><smiles>O=c1c(O[C@@H]2OC(CO)[C@H](O)[C@H](O)[C@H]2O)c(-c2ccc(O)c(O)c2)oc2cc(O[C@@H]3O[C@H](CO)[C@H](O)[C@H](O)[C@H]3O)cc(O)c12</smiles>

$\mathbf{E}$<smiles>C[C@@H]1OC(OCC2O[C@@H](Oc3c(-c4ccc(O)c(O)c4)oc4cc(O)cc(O)c4c3=O)[C@H](O)[C@@H](O)[C@H]2O)[C@H](O)[C@@H](O)[C@H]1O</smiles>

$\mathbf{F}$

\section{CONCLUSION}

Flavonoids exhibit a wide range of activities so their source plants could be used to prepare various medicines and cosmetics to meet the increasing global demand. In higher plants, Flavonoids are involved in UV filtration. Some flavonoids have inhibitory activity against organisms that cause plant disease e.g. Fusarium oxysporum. ${ }^{[2]}$ Flavonoids might induce mechanisms that affect cancer cells and inhibit tumor invasion. Flavonoids are most commonly known for their antioxidant activity. The activities of the flavonoids especially Eupatilin-7-O-2,6-dirhamnosylgalactoside isolated from the above plant could be further investigated and used for preparing products for a specific purpose.

\section{References}

[1] Chopra,G.L. Angiosperms Systematic and Life cycle, S. Nagin and co. Jalandhar, Punjab, India. (1969).

[2] Gaur, R.D., Flora of the District Garhwal North West Himalaya: With Ethno botanical Notes. Transmedia Publication, Srinagar Garhwal, 1999, pp: 375-376.

[3] Pangtey, Y. P. S.. A note on the collection of Pteris puberula Ching (Pteridaceae: Pteridophyta) in the north-western Himalaya from Kumaon Hills. Journal of the Bombay Natural History Society 2005, 102: 260.

[4] Singh RH and Udupa KN Studies on the Indian indigenous drug punarnava (Boerhaavia diffusa). controlled clinical trial in nephritic syndrome. Journal of Research in Indian Medicine7: (1972), 28-33

Part IV: Preliminary

[5] Lad, V.. The complete Book of Ayurvedic Home Remedies, Three Rivers Press: New York. 1999.

[6] Guhabakshi,D.N, Sensarma,P., and Pal, D.C., A lexicon of Medicinal Plants of India, Vol. I, Naya Prakash, Calcutta, India. 1999.

[7] Bhalla TN, Gupta MB, Bhargava KP. Antiinflammatory activity of Boerhaavia diffusa. J Res Ind Med 1971; 6: 11-15.

[8] Chude,M.A., Orisakwe,O.E., Afonne,O.J., Gamaniel,K.S. and Vongtau,U.H. Hypoglycemic effect of the aqueous extract of Boerhavia diffusa leaves, Indian Journal of Pharmacology, (2001). v. 33: p. 215-216.

[9] Jain GK and Khanna NM. Punarnavoside: A new antifibrinolytic agent from Boerhaavia diffusa L. Indian Journal of Chemistry 28(B): (1989), 163-166.

[10] Adesina,S.K. Anticonvulsant properties of the roots of Boerhavia diffusa, Quaterly Journal of Crude Drug Research, v. 17: (1979). p. $84-86$.

[11] Vijayalakshmi,K., Misra,S.D., and Prasad,S.K. Nematicidal properties of some plant materials against second stage juveniles of Meloidogyne incognita, Indian Journal of Entomology, (1979), v. 41(a): p. 326-331.

[12] Nadkarni AK Indian Materia Medica. A.K. Nadkarni, Popular Prakashan Pvt. Ltd., Bombay, Maharashtra, India, 1(1976): 203-205.

[13] Olukoya,D.K., Tdika,N., and Odugbems,J. Antibacterial activity of some medicinal plants from Nigeria, J. of Ethnopharmacology, v. 39, (1993): p. 6972. 
Eupatilin-7-O-2,6-dirhamnosylgalactoside from the leaves of Boerhaavia diffusa linn.

[14] Mishra, J.P. . Studies on the effect of indigenous drug Boerhaavia diffusa Rom. on kidney regeneration. Indian Journal of Pharmacy; 12:59, 1980

[15] Chandan,B.K, Sharma,A.K., and Anand, K.K. Boerhavia diffusa a study of its hepatoprotective activity, J. of Ethnopharmacology, v. 31,(1991): p. 299-307.

[16] Awasthi,L.P., and Menzel,G. Effect of root extract from Boerhavia diffusa containing an antiviral principle upon plaque formation of RNA bacteriophages, Zentralblatt Fur. Bakteridogie (1986), v. 141: p. 415-419.

[17] Pari L, Amarnath Satheesh M Antidiabetic activity of Boerhaavia diffusa L.:effect on hepatic key enzymes in experimental diabetes. Journal of Ethnopharmacology (2004), 91(1): 109-113.

[18] Cuendet M, Hostettmann K, Potterat O, Dyatmiko W. Iridoid glucosides with free radical scavening properties from Fagraea blumei. Helv. Chim. Acta. (1997). 80: 1144-1152.

[19] Mabry, T. J. and Markham, K. R.. The Flavonoids (Harborne, J. B., Mabry, H. and Mabry, T. J. eds), p-41, Chapman and Hall, London. 1975

[20] Agrawal PK. Carbon-13 NMR of flavonoids. Amsterdam, Elsevier Science Publishers, 1989.

[21] Markham, K.R., H. Geiger ${ }^{1}$ H-NMR spectroscopy of flavonoids and their glycosides in hexadeuterodimethylsulfoxide, in: Harborne JB (Ed.), The Flavonoids, Advances in Research since 1986. Chapman and Hall, London, 1994. pp: 441-497.

[22] Mabry, T. J., Markham, K. R. and Thomas, M. B. Techniques of Flavonoidal Identification. A. P. London. 1970.

[23] Markham,K.R. Techniques of flavonoid identification, A.P. London, (1982). p. 52.

[24] Galeotti, F; Barile, E; Curir, P; Dolci, M; Lanzotti, V (2008). "Flavonoids from carnation (Dianthus caryophyllus) and their antifungal activity". Phytochemistry Letters 1: 44. 